\title{
Talent Development Practices: A Revisit as an Imperative for Talent Retention
}

Bathmavathy Dalayga, Shathees Baskaran and Nomahaza Mahadi

To Link this Article: http://dx.doi.org/10.6007/IJARBSS/v11-i2/8578

DOI:10.6007/IJARBSS/v11-i2/8578

Received: 22 December 2020, Revised: 23 January 2021, Accepted: 10 February 2021

Published Online: 21 February 2021

In-Text Citation: (Dalayga et al., 2021)

To Cite this Article: Dalayga, B., Baskaran, S., and Mahadi, N. (2021). Talent Development Practices: A Revisit as an Imperative for Talent Retention. International Journal of Academic Research in Business and Social

Sciences, 11(2), 330-348.

Copyright: (c) 2021 The Author(s)

Published by Human Resource Management Academic Research Society (www.hrmars.com)

This article is published under the Creative Commons Attribution (CC BY 4.0) license. Anyone may reproduce, distribute, translate and create derivative works of this article (for both commercial and non-commercial purposes), subject to full attribution to the original publication and authors. The full terms of this license may be seen

at: http://creativecommons.org/licences/by/4.0/legalcode

Vol. 11, No. 2, 2021, Pg. 330 - 348

http://hrmars.com/index.php/pages/detail/IJARBSS

JOURNAL HOMEPAGE

Full Terms \& Conditions of access and use can be found at http://hrmars.com/index.php/pages/detail/publication-ethics 


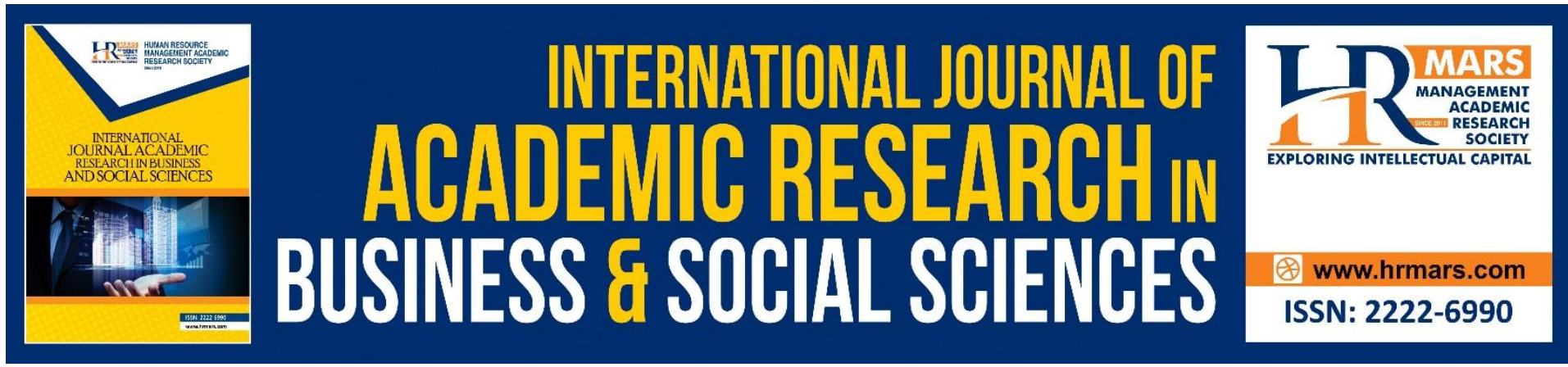

\title{
Talent Development Practices: A Revisit as an Imperative for Talent Retention
}

\section{Bathmavathy Dalayga, Shathees Baskaran and Nomahaza Mahadi}

International Business School, Level 10, Menara Razak, Universiti Teknologi Malaysia, Jalan Sultan Yahya Petra, 54100 Kuala Lumpur.

Email: ssbathma@gmail.com, shathees@utm.my

\begin{abstract}
A rapidly advancing technology has transformed the scene of employment making the talents increasingly attractive and marketable across the globe, making them a new differentiator in the human capital market. This, in turn, has created tremendous pressure on the organisation to ascertain talent retention. As a result, scholarly endeavors are continuing to address the dynamics of talent and therefore, talent development is gaining attention as a new mechanism to address challenges confronting these organisations. In explaining this phenomenon, there have been also consistent calls to investigate work engagement as well across different settings to further explore employee retention. Therefore, this study attempts to address underexplored constituents in explaining intention to stay from a talent perspective including talent development practices and work engagement. A structured selfadministered questionnaire was used in this research to collect data from 287 respondents from the Malaysian private healthcare industry. Structural equation modeling was used to analyse the data. The results discussed in terms of evolutionary findings in the realm of theory and practice of talent development. It is envisaged that the findings were an incremental contribution to existing literature and also of great importance to organisational behavior scholars, human resource experts, and workplace policy regulators.
\end{abstract}

Keywords: Talent Development, Training And Development, Career Development, Intention To Stay, Work Engagement

\section{Introduction}

Talent management has become an interdisciplinary focus in promoting the competitive advantage of businesses and also has become a new mechanism for overcoming talent issues in the market (Milliman, Gatling \& Kim, 2018; Cascio \& Boudreau, 2016). Today, it has been expanded and moved from the infancy stage to the maturity stage (Gallardo Gallardo et al., 2017). Talent is now extremely mobile, and competitive (Boudreau, Ramstad \& Dowling, 2015) among companies because performing talents are moving from and crossing the national to international boundaries with the transmission of learning becoming highly significant (Beck and Harter, 2018; McElroy \& Weng, 2016). 
In congruence with that, organisations are competing and strategizing their recruitment plans to overcome the shortage of talents, skills, and expertise. According to Tlaiss, Martin, and Hofaidhllaoui, (2017), the art of effectively managing talent globally and locally has materialized due to vigorous efforts at enhancing the competitive advantages of firms. Talent Management departments and top management should be active in eliminating the issue of talent shortages, by applying appropriate talent management policies and strategies (Aman et al., 2018) that takes into account various constituents like talent development including work engagement.

Talent development noticeably has widespread its functions lately (Mehdiabadi \& Li, 2016). The world's biggest association in the human capital development field, American Society for Training and Development (ASTD) in 2014 changed its name to the Association for Talent Development (ATD). This transformation prominently marks the importance of talent development nowadays (Ikuomola, 2015). Yet, talent development has not been gaining enough focus among the researchers. Although the researches made in the past are limited (Mehdiabadi \& Li, 2016) on this issue, the importance of talent development is evident from the success in managing talent by different companies (Garavan, Carbery, \& Rock, 2012). Even though the importance of talent development strategies is gaining its prominence, there are still notably limited quantitative studies in developing nations that examine the factors and measurements to boost the intention of employees to stay (Pandita \& Ray, 2018). Therefore, researchers observe that although talent management and talent development are closely related, they are needed to be addressed and treated separately (Scullion \& Collings, 2011).

A notable change is occurring in the healthcare and medical field due to the patient's revolution in their behavioural profile, put more weight to revamp the management of personnel and talents in the hospital. The healthcare sector needs more sophisticated technologies and skilled personnel to deliver the best patient care. Despite this, healthcare facing acute talent shortage worldwide. The World Health Report (2016) reported the global shortage for physicians, whereby it is estimated that 57 countries have an absolute shortage of 2.3 million physicians, nurses, and midwives. With this shortage, patients are suffering because the healthcare workforce is not prepared to deal with their health needs. It is difficult to offer quality healthcare services to patients because of the unavailability of professionally sound, technically skilled and personally committed personnel in the hospital. Strong educational efforts, employee training and development, and career development practices benefit hospitals in various ways.

From the literature, it is obvious that talent development is underdeveloped particularly in the Malaysian context and there is much room to grow in the future. Additionally, work engagement also plays a significant role in retaining talent in an organisation. Hence, it is the aim of this study to address underexplored constituents in explaining the intention to stay from a talent perspective including talent development practices and work engagement in Malaysia. Thus, the research will investigate the following objectives:

a. There is a significant relationship between talent development and intention to stay.

b. There is a mediating effect of work engagement on the relationship between talent development and intention to stay. 


\section{Literature Review \\ Talent Development}

Talent development processes are to develop employee skills and knowledge. Chhabra and Mishra (2008) stated that "investing in staff is far less expensive than replacing them, which is estimated to cost about one-and-a-half years of a departing staff's annual salary" (p. 50) which highlights the risks of employee turnover. Studies conclude that companies in developed nations realized the importance and existence of the relationship between employee development and their intention to stay (Agarwal, 2019). This has been proven by providing their employees with talent development programs and opportunities to improve themselves. Talent development, in order to be useful and earn a rightful role, requires it to be treated as a separate entity of talent management rather than being embedded in it. Furthermore, several scholars (e.g. Isa, Ibrahim, Jaaffar, \& Baharin, 2018; Mehdiabadi and Li, 2016; Sheehan, 2012 and Garavan et al., 2012) found that the talent development concept has not received the attention it deserves although a few academic papers on it had been written. This is because an individual entering an organisation already possesses the talent and what remains is for it to be continuously strengthened. By reviewing various definitions and terms of talent management practices, the two prominent processes of talent development were identified for this study, namely training and development (Clifford \& Thorpe, 2007) and career development (Christensen, 2005:167 as an important variable in understanding the talent development phenomena at a greater depth.

\section{Training and Development}

Patrick (2000) defines training as an efficient progress of the knowledge, proficiency, and skills that should possess by an employee to do the duties effectively. Whereas, development, is a continuous effort to form proficiencies of the task performance for the long term. As such, it is vitally important to have training and development to provide support for talents in order to enhance their competencies and skills (Huang, Strawderman, Babski-Reeves, Ahmed, \& Salehi, 2013). Managing people is a delicate art. The authors claim that the structured and planned training and development practice is increasingly being used in an organization in an orderly manner to groom existing talents is a must. The employees of today's age are always on the lookout to expand their skills to enhance their competence levels. In addition, managing global and multi-varied employees impose a huge challenge with different nationalities and cultural settings too. Therefore, organisations that invest in training and development could overcome the talent war by retaining their talents and enhancing the talents' intention to stay. According to Huertas-Valdivia et al., (2018), training and development become the best substitute in areas where skills can be mastered fast to increasing salary. Therefore, training and development are very crucial for employees.

\section{Career Development}

Career development gained its popularity through various research platforms in developing and creating career growth opportunities for employees to stay in the organisation. Career development becomes an important determinant in human development processes to manage job challenges such as retention, recruitment, training, promotion, succession planning and so on. Career development is a series of positions occupied by an employee in his or her lifetime. It is an employee's continuous progress, skill acquisition, and experience in a particular field. Although usually career development is seen as the jobs undertaken by an employee throughout his or her life, it covers a wider meaning beyond this definition. 
Lifelong and long-term career development hardly fails and does not stop with only one career role. Multiple career roles and development are necessary for volatile business environment. Possessing a single growth of a career path will lead to failure and drown the organisation. Employers who assign priorities to career development mechanisms for their employees create a two-way long-lasting relationship that benefits the organisation (Festing and Schafer, 2014). Therefore, serious consideration should be given to developing career progression to uphold the employee's intention to stay.

\section{Work Engagement}

The definition of work engagement as stated by Kahn (1990) is "the harnessing of organisation members' selves to their work roles; in engagement, people employ and express themselves physically, cognitively and emotionally during role performances" (p. 694). Work engagement has gained the attention of researchers as a relatively new construct due to its contribution in enhancing firm performance and attaining sustainable competitive advantage (Blazej, 2018). Those involved in their jobs would work harder and would most likely return an outcome that satisfies the customer and the needs of the company since they have high energy and self - efficacy. It is also found that they utilize their skills when carrying out their job and find that their work is challenging and stimulating and that their work provides them with a sense of personal accomplishment.

\section{Intention to Stay}

Past studies are more deliberate about employee turnover and did not specifically point out whether it is voluntary or involuntary quitting (Lee, Hom, Eberly, \& Li, 2018). However, lately, the intention to stay has been accepted as the best predictor of turnover activities. It is an important variable to access the level of willingness to stay in an organisation (Mehrez \& Bakri, 2019). Moreover, many studies (e.g. Ghosh et al., 2013; Ghazali et al., 2014; Armstrong-Stassen et al., 2015; and Yang et al. 2015) have been carried out on this topic signaling its importance in reducing companies' recruitment cost. Therefore, it is wise to concentrate more on the intention to stay rather than a turnover intention where it has proven to have many benefits. Hence, in this study, intention to stay is chosen as a dependent variable because its relationship with talent shortage or talent retention is closely related. In short, employees who intend to stay generally do not think about leaving the organisation, rather it is their conscious and deliberate willingness to be with the organisation (Dai, Zhuang, \& Huan, 2019).

\section{Human Capital Theory}

This research utilizes human capital theory which emphasizes talents as an exceptional asset to an organization and based on that relevance, it was chosen as an underpinning theory for the current study. Training and development and education are two major successors in human capital theory. It underlines that information, experience, and knowledge employee obtain from training development is a form of valuable capital and a great investment that produces returns (Becker, 1962). There are many studies about the talent management field that uses human capital theory apart from the resource-based view theory. Besides that, human capital theory generally supports and stimulates human capital or talents to operate freely. According to Becker 1992, "all workers are intrinsically identical" as he attempts to prove that "greater knowledge tends to raise the benefits from specialization, and thus tends to raise the optimal division of labor" (p. 318). 


\section{Job Demands-Resources (JD-R) Model}

This research is basically about developing a talent concept, therefore, to emphasize the talent concept at greater detail, the second reformulated theory by Bakker (2011) called JD$\mathrm{R}$ was used. The JD- $\mathrm{R}$ model has demonstrated usefulness as a comprehensive yet parsimonious model to conceptualize and investigate engagement, well-being, and work performance, since its initial development by Demerouti et al., (2001). The JD-R model has been used by numerous occupational settings, regardless of the specific demands and resources involved. It was locally tested by Rothmann and Joubert (2010) and globally for numerous occupational groups (which includes teachers, dentists, hospital nurses, blue-collar and white-collar workers, and private home-care professionals), and the call center workers (Llorens et al., 2006). Even when the JD-R model is applied in a different national and international context, the basic structure of it is maintained. The JD-R model assumes that job resources and personal resources, independently or in combination, predict worker engagement, especially when the job demands are high. This theory is chosen in order to support the view of the employee as a proactive means in the talent development process and to understand the changes in human capital over time. Even though it mostly relates to motivational factors, in this research context, it is used to encourage human capital obligation to an organisation. This theory is idealized from the thought that some results will be formed from their behaviours.

\section{Hypotheses Development}

\section{Training and Development and Intention to Stay}

Training and development is needed continuously for improvement and to keep the talent at par and always competent (Knassmuller \& Veit, 2016 and Dubey \& Gunasekaran, 2015). Training and development work as a pathway in creating a competent talent. A competent talent will always be eager to learn more and more and easily could fill the gap of shortages of talent or vacancies (Huang \& Su, 2016). Besides that, training and development is a powerful motivational factor that will tie an employee to an organisation to serve longer (Burgard \& Görlitz, 2014). According to this author, training human capital brings a lot of good deeds to the organisation and to the employee. Another research by Memon et al., (2016), highlights that employees are made to believe that their admission into training and development activities indicates their value in the organisation. Considering the reciprocity rule of Human Capital Theory, training is a booster for every workforce in delivering his or her task excellently. Therefore, it will give a high level of satisfaction that employers are considering them as an asset to the organisation and in turn, it will increase their intentions to stay. Subsequently, the more engaged the employees with training and development programs, the higher the tendency to retain them in organisations hence to overcome talent shortages.

Acknowledging that training and development has a positive effect on employee intention to stay, the following hypothesis is formulated:

$\mathrm{H} 1$ : There is a positive relationship between training and development and intention to stay.

\section{Career Development and Intention to Stay}

Promising career development plans and strategies never fail to inspire talents. Career development could differ from one organisation to another based on their goals and strategic 
plans. Promising and enhanced career plans will tie a star worker in his/her job. In overcoming talent shortage, a crystal-clear career development plans such as promising and transparent succession plan will always have a positive effect (Ali et al., 2019). Through increasing the skills workers have and the chances of rising their careers, companies can successfully maintain their valued staff (Abraham, 2019). As such, a study by Weng and McElroy (2012) argued that career growth reduced the number of turnover intentions. It will stimulate employees' career satisfaction which in turn maintains the talent within the companies (Schein \& Van Maanen, 2016). Apart from that, Zheng and Kleiner, (2001) argued that career planning, growth, and learning opportunities are the top three reasons for an employee to stay with an organisation.

Based on the discussion above, the following hypothesis is proposed:

$\mathrm{H} 2$ : There is a positive relationship between career development and intention to stay.

\section{Work Engagement as Mediator}

\section{Training and Development, Work Engagement and Intention to Stay}

Employees who are engaged in their work have been found to perform better than nonengaged counterparts, as they are energetic and enthusiastic about their jobs and deeply immersed in their work (Lu et al., 2016), experience more positive emotions, transfer their engagement to others, experience better health and craft their own job and personal resources (Bakker et al., 2007). The past studies proved that training and development positively related to intention to stay. A recent study by Fletcher et al., (2018), empirically proved that training and development has a high significance on employee intention to stay when an employee is engaged in their work.

Although there are many studies in respect of training and development and work engagement separately, there is a little study that sought to assess the impact of training and development on employee work engagement (Semwal \& Dhyani, 2017). Apart from this, studies on the mediating role of work engagement specifically on training and development and intention to stay are also scarce. There are studies that correlate the negative relationship between training and development and intention to stay (Nawaz et al., 2015 and Cheng \& Waldenberger, 2013). Therefore, the mediating role of work engagement was introduced in this present study to have a stronger sense of belongings in the organisation. With that, hypotheses are worth to be tested in the context of Malaysian private health care.

Based on the discussion above the proposed hypothesis was:

H3: Work engagement mediates the relationship between training and development and intention to stay.

\section{Career Development, Work Engagement and Intention to Stay}

Employees who feel that they are highly engaged with their work and as a whole, satisfied with their careers are happy in their lives (Joo \& Lee, 2017). Based on prior researches on employee work engagement, the engaged employees tend to show positive organisational outcomes, which includes more customer satisfaction, higher productivity and profit, lower turnover intention (Harter, Schmidt, \& Hayes, 2002), higher organisational commitment (Schaufeli \& Bakker, 2004), more in-role and extra-role behaviour (Schaufeli et al., 2006), and work-family satisfaction (Bakker et al., 2013). Although research on work engagement and 
career has been carried out intermittently, given these concepts' positive and relevant influences on organisations, more research is necessary to understand them and investigate their relationships (Lee et al., 2016).

Thus, based on these arguments, the following hypothesis was formulated:

H4: Work engagement mediates the relationship between career development and intention to stay.

\section{Conceptual Framework}

The conceptual framework of the study is shown in Figure 1. There will be two independent variables which are training and development and career development and one dependent variable namely intention to stay. This relationship is further mediated by work engagement.

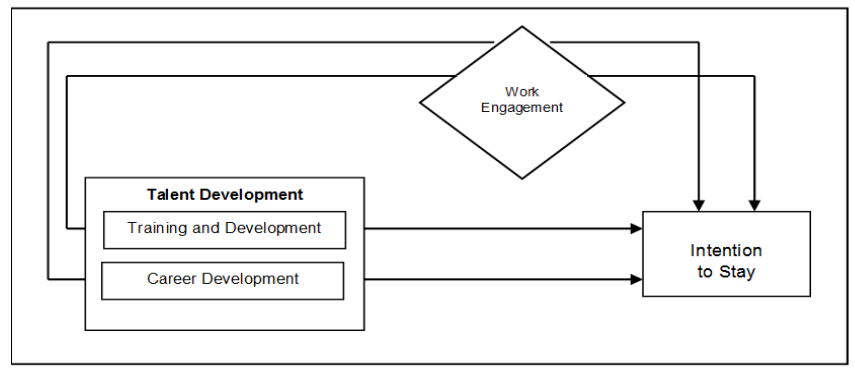

Figure 1: Conceptual Framework

\section{Research Methodology Research Design}

A quantitative method is more appropriately chosen with standardised questionnaires to achieve the intended study objectives of this report. According to Cooper and Schindler, quantitative research methods have been well recognized for much longer than qualitative research methods (2011). The first is mainly to build new-fangled philosophies or hypotheses that will be evaluated through observable means. Balnaves and Caputi (2001) noted that quantitative analysis is not biased and error-free.

\section{Sample and Data Collection}

The target population of the current study is private healthcare organisations operating in Malaysia, while the unit of analysis is the individual employees who have been working in these organisations for more than a year. Large organisations such as Kumpulan Perubatan Johor (KPJ) and Columbia Asia typically dominate the majority of private health care in Malaysia. These private healthcare organisations are selected on the basis of the bed occupancy rate, which has 50 beds and above. This is because healthcare institutions with occupancy rates of more than 50 beds seem to have higher utilization standards of facilities and multiple programmes to help patients with the most new, advanced and complex medical equipment and resources where diversified demands and talent development can occur.

A survey questionnaire was created and used to collect primary data from private healthcare organisations in Malaysia based on variables from established literature. Neuman (2011) believed that through the advantages of self-administered questionnaires, biases are 
avoided. Both respondents were advised that the responses would be confidential only and

\begin{tabular}{|llc|}
\hline Author & Construct & $\begin{array}{c}\text { Number of } \\
\text { Items }\end{array}$ \\
\hline Schmidt, (2007) & $\begin{array}{l}\text { Training and } \\
\text { Development }\end{array}$ & 7 \\
\hline $\begin{array}{l}\text { Weng, Q., McElroy, J. C., Morrow, P. C., \& } \\
\text { Liu, R., (2010) }\end{array}$ & Career Development & 7 \\
\hline $\begin{array}{l}\text { Schaufeli, W. B., Bakker, A. B., \& Salanova, } \\
\text { M., 2006 }\end{array}$ & Work Engagement & 9 \\
\hline Cammann et al., 1979; Seashore et al.,1982 & Intention to Stay & 4 \\
\hline
\end{tabular}

only used for academic purposes. 360 questionnaires were distributed and 287 were returned, indicating a response rate of 79.72 percent.

\section{Measures and Instrumentation}

Well-developed measures were adopted and adapted in this research. The items for training and development measures talent capabilities with the training. Career development measures employee motivation to work harder and to increase their competency to stay in the organisation. Work engagement items were adapted from a shortened Utrecht Work Engagement Scale (UWES). Next, the measures for intention to stay were tested on the decision and willingness of employees about their future moves or staying in their organisation. In this research, a 7-point Likert scale was used, ranging from 1 indicating strongly disagree to 7 , which indicates strongly agree towards the statements given.

The instrumentations used in this research are as stated in Table 1.

Table 1. Test Instruments

Findings and Discussion

Respondent Profile

In this study, the proposed relationships, and the influences of exogenous variables on the dependent variable were analyzed using SEM. SEM is a method with a theory through which the researcher proposes to test the relationship among the chosen variables. $18.8 \%$ of respondents were male while $81.2 \%$ made up female respondents. Most of the respondents are educated, and about $52.3 \%$ from the samples have Diploma Qualification. From a total of 287 respondents, $65.5 \%$ falls into the age group of $26-39$ years old.

\section{Reliability Test}

Reliability assesses the degree of consistency and stability of a variable. Sekaran and Bougie (2010) articulated that the reliability of a measure is an indication of the stability as well as the consistency with which the instrument measures the concept and helps to assess the 'goodness of the measure'. In other words, the higher value would indicate that the respondents understood the questions within the questionnaire. The most used test for internal consistency is using the Cronbach- $\alpha$ coefficient (Sekaran \& Bougie, 2010) which can be obtained using SPSS. A higher coefficient value depicts greater internal consistency. Malhotra (2004) ascertained that any $\alpha$ above 0.60 is considered reliable and acceptable. Furthermore, according to Di lorio (2005), the Cronbach alpha value that is lower than 7 for shorter scales are acceptable, where it shows higher interrelatedness between the items. 
Therefore, the instruments were maintained as intact as it was prepared for the actual study. The results revealed that the Cronbach- $\alpha$ for all the constructs was above 0.60 (i.e., from 0.661 to 0.960 ) concluded that the test instruments met the requirements.

Table 2. Reliability Results of Survey Instrument

\begin{tabular}{|l|l|}
\hline $\begin{array}{l}\text { Variables under } \\
\text { investigation }\end{array}$ & $\begin{array}{l}\text { Cronbach } \\
\text { Alpha }\end{array}$ \\
\hline Training development & 0.949 \\
\hline Career development & 0.960 \\
\hline Work engagement & 0.943 \\
\hline Intention to stay & 0.661 \\
\hline
\end{tabular}

\section{Results of the Tests of the Hypotheses}

The research tested the direct relationships of training and development and career development effects on intention to stay. Additionally, a mediating effect of work engagement was also tested against these relationships. The results of the hypotheses testing are shown in Table 3.

Based on Table 3, the t-value is 2.392 and 2.030 while the p-value is $0.017<0.05$ and $0.043<$ 0.05 for training development and career development, respectively. This result shows a significant relationship between training development and intention to stay and career development and intention to stay. The standardized beta values of 0.213 (for training development) and 0.182 (for career development) also shows that there is sufficient support for a positive association between training development and career development and intention to stay. Therefore, both hypotheses, $\mathrm{H} 1$ and $\mathrm{H} 2$ are accepted.

There are two indirect or mediated relationships in this study. Like the hypotheses testing for direct relationships, path coefficient $(\beta)$ and t statistics, would be used as the criteria. As discussed earlier, the Smart-PLS version 3.2.7 provides the specific indirect effect feature that is derived from a bootstrapping procedure to produce the above-mentioned criteria. In this regard, the hypotheses testing on two mediated relationships are treated the same way as to direct relationships. The bootstrapping result showed a path coefficient $(\beta)$ of 0.104 and tstatistics value of 2.683 for the mediating role of work engagement towards the relationship between training and development and intention to stay. These values indicate that $\mathrm{H} 3$ is supported. The bootstrapping result for career development showed a path coefficient $(\beta)$ of 0.136 and t-statistics value of 3.41 for the mediating role of work engagement towards the relationship between career development and intention to stay. These values also indicate that $\mathrm{H} 4$ is supported. 
Table 3. Hypotheses Test Results

\begin{tabular}{|c|c|c|c|c|c|c|}
\hline $\mathbf{H}$ & Relationship & $\beta$ & SD & $\begin{array}{l}\text { T } \\
\text { Value }\end{array}$ & $\begin{array}{l}\text { P } \\
\text { Value }\end{array}$ & Support \\
\hline $\mathrm{H} 1$ & TD $>$ ITS & 0.213 & $\begin{array}{l}0.08 \\
9\end{array}$ & 2.392 & 0.017 & Yes \\
\hline $\mathrm{H} 2$ & $C D>I T S$ & 0.182 & $\begin{array}{l}0.08 \\
9\end{array}$ & 2.030 & 0.043 & Yes \\
\hline H3 & TD->WE-> ITS & 0.104 & $\begin{array}{l}0.04 \\
0\end{array}$ & 2.683 & 0.015 & Yes \\
\hline $\mathrm{H} 4$ & CD->WE->ITS & 0.136 & $\begin{array}{l}0.03 \\
8\end{array}$ & 3.41 & 0.014 & Yes \\
\hline
\end{tabular}

\section{Discussions}

\section{Training and Development and Intention to Stay}

This hypothesis tests the relationship between training and development and intention to stay. Based on the result, it was concluded that there is a significant relationship between training and development and intention to stay. In the context of this study, the role of training and development will increase the employee's intention to stay in the organisation and will lead to a lower percentage of turnover. This research confirmed the positive relationship between training and development and intention to stay and the findings are consistent with the past studies such as Nguyen and Shao, (2019); Khawaja and Nadeem, (2013); Chew and Chan, (2008) and Deckop et al., (2006). Similar findings were reported by Huang and Su, (2016) also confirms that job training is negatively correlated with turnover intention, which means otherwise. This study clearly reinforced that providing proper training and development will have a positive effect on employee intention to stay.

\section{Career Development and Intention to Stay}

The result of the analysis indicated that there is a positive relationship between career development and intention to stay. In line with previous findings, this study supported the role of career development in increasing the level of employees' intention to stay and in increasing the level of their commitment (Nkechi \& Dialoke, 2017; Karavardar, 2014). Besides this, the present study's results support the works of Kim et al., (2015); McElroy and Weng (2016) and Weng and McElroy (2012). In the study of Weng and McElroy's study, career development is negatively related to turnover intentions, which means career development has a positive effect on the intention to stay. A clear career growth path will always lead to a successful effort in retaining talents. This will avert the intention to leave.

\section{Mediating Effect of Work Engagement}

Based on the statistical analysis, a mediating effect of work engagement was evident on the relationship between training and development, career development towards intention to stay. The result of the analysis indicated that there was a positive relationship between the variables tested. Moreover, these findings were supported by past literature (e.g. Sheehan et al., 2019; Gupta \& Shaheen, 2017; Memon et al., 2016, 2018). An employee who has received sound training would feel engaged, have a positive outlook on their job, and would not think of leaving the organisation (Karatepe, 2013). This is because training and development stimulate personal development (Bartlett, 2001) and as a result, employees may feel engaged 
in their job happily and stays in the organisation for longer (Karatepe \& Olugbade, 2016). The positive relationship is very vital to all organisations in the modern and volatile work landscape to retain their employees.

Next, this study's aim is to test the level of influence of work engagement on individual career development which will lead to their intention to stay in an organisation. Proper and enhanced career development with the influence of work engagement is a must to retain the employees. Recent studies stated that there is a significant relationship between career development and work engagement (Joo \& Lee, 2017; Akkermans et al., 2013). According to them, career plans make workers to highly focus and be engrossed in their job, which would sustain their intention to stay. This is in line with the hypothesis $\mathrm{H} 4$ which predicts that there is a mediating effect of work engagement on the relationship between career development and intention to stay.

\section{Conclusion}

Overall, the findings of the study showed that all hypotheses were supported and had a positive relationship with the intention to stay. The findings indicated that work engagement mediates the relationship between talent development practices and the intention to stay. Past research reflects that high turnover due to the failure of a company's retention strategy to make their employee stay has become a continual problem (Yin-Fah et al., 2010). Moreover, it is very costly for employers to attract and find new skilled employees with suitable experiences and skills to replace the talents that decide to leave. Therefore, some of the best strategies have to be implemented in order to attract them and one of them is training and development. Organisations that invest in training and development win the talent war by keeping their talents with them and could earn employees' intention to stay.

Apart this, a clear career growth path will always lead to a successful effort in retaining talents. Attracting an employee with the right talent and career growth will increase the opportunity of an organisation to retain a talented employee. An organisation needs to have an effective recruitment policy to promote a scientific selection of prospective employees. High-calibre employees well-versed in their careers are definitely committed to serving their organisation. Therefore, facilitating career development boosts their motivation to have a sound career commitment which leads them to have the intention to stay. This will avert the intention to leave.

Employees who work hard, are enthusiastic about their work, and feel engrossed in their work are committed to their organisation, display extra-role performance, and have high levels of intention to stay. Empirically, Schaufeli and Bakker (2004), demonstrated that work engagement reduced turnover intentions among employees in four different service organisations in the Netherlands. Therefore, once work engagement is cultivated by providing satisfying training and development and career development, there will be a strong bond between employee and employer which in turn, will ensure the permanency of the employees in one organisation, as highlighted by the findings of the present study.

Therefore, it was concluded that training and development, career development and work engagement will increase employees' intention to stay in the organisation.. As such, the best strategies must be implemented to attract them. These results articulated that talent 
development has an important function in retaining and boosting employee intention to stay in the organisation.

This study has both theoretical and managerial contributions. This study has contributed to theory by extending the knowledge and filling the gap that exist in the study about talent development. This study used a combination of two theories from talent management factors and motivational factors such as Human Capital Theory and Job Demands-Resources (JD-R) Theory. Though these theories are well established, the present study used a different tactic to gain new insights into talent management. The incremental contribution of this study has added further to validating existing theories in relevance to talent management.

Second, the result of this study empirically supports the relationship among all the variables identified. Based on this, this research extended the knowledge and filled the gap by identifying the effects of talent development practices on the intention to stay. The respondents being from the Malaysian Private Healthcare providers is another supporting point for the empirical results. The positive and significant relationship between work engagement as a mediator on the relationship between training and development, career development on the intention to stay has also lent empirical support. Therefore, it is recommended to shift the focus of talent management towards different sectors in Malaysia with more published academic literature.

From the managerial perspective, it has offered insights to the organisations about the benefits of talent development practices in overcoming their talent retention challenges. Through the findings, the practitioners shall plan and revitalize their talent management programs to make their valuable employees stay. Managers are encouraged to find the ways and means to make their subordinates perceive that the organisation would take care of their careers.

Besides that, the findings of this study can also be useful to other sectors like public hospitals or public services department and private sectors because the talent development process is a must to all the employees regardless of organisation types. The findings of the study could be helpful in increasing employee intention to stay in one organisation for a longer time frame in this volatile globalization and borderless career world.

\section{Limitations and Recommendation for Future Research}

Irrespective of the managerial and theoretical contributions, this study also has some limitations which could be considered as an opportunity to improve in further studies to get more reliable results. Firstly, due to access and resource limitations, this study is only conducted in ten Malaysian private healthcare providers and in selected states. Besides that, there was very limited information was made accessible about Malaysian private healthcare. This may be since private healthcare providers are standalone and operating in a competitive environment, hence information was considered rather private and confidential.

Secondly, it would be valuable to examine the relationship between training and development, career development, work engagement, cultural intelligence, and intention to stay using the different methodologies of statistical tools such as AHP, AMOS, qualitativebased research, or even mix-methods research. More importantly, the triangulation of 
research findings will further validate current results and provide greater insights to academia, industry and also policymakers.

Based on the limitations of the current study, directions for future work can be recommended. It is suggested that by employing longitudinal procedures on a similar group of participants, the results may improve with clear descriptions of the relationship between talent development practices, work engagement, with the intention to stay. Therefore, it is recommended in the future, that a longitudinal study is carried out.

The present research has prompted more empirical research in the area of talent management, particularly on talent development practices in private healthcare in Malaysia. Therefore, it is recommended to shift the focus of talent management towards different sectors in Malaysia with more published academic literature.

\section{References}

Abraham, I. (2019). Relation Between Career Orientations Of Employees And Their Intention To Stay : A Study Of The Hotel Industry. The Research Journal of Social Sciences, 10(1), 64-73.

Agarwal, R. (2019). Talent Management for Empirical Enlargement. International Journal of Engineering and Management Research, 09(06), 83-86. doi: 10.31033/ijemr.9.6.14.

Akkermans, J., Schaufeli, W. B., Brenninkmeijer, V., \& Blonk, R. W. B. (2013). The Role Of Career Competencies In The Job Demands-Resources Model. Journal of Vocational Behavior, 83, 356-366. doi:10.1016/j.jvb.2013.06.011

Ali, Z., Bashir, M., Mehreen, A. (2019). Managing Organisational Effectiveness through Talent Management and Career Development: The Mediating Role of Employee Engagement. Journal of Management Sciences, 6 (1), 62-78.

Aman, A., Yunus, Y. M., Embong, Z., Maelah, R., \& Ahmad, A. A. (2018). Overcoming Talent Shortage through Impact Sourcing. Jurnal Pengurusan, 54, 1-15.

Armstrong-Stassen, M., Freeman, M., Cameron, S., \& Rajacic, D. (2015). Nurse Managers' Role In Older Nurses' Intention To Stay. Journal of Health Organisation and Management, 29(1), 55-74. doi:10.1108/jhom-02-2013-0028

Bakker, A. B. (2011). An Evidence-Based Model of Work Engagement. Current Directions in Psychological Science, 20(4), 265-269. doi.org/10.1177/0963721411414534

Bakker, A. B., \& Xanthopoulou, D. (2013). Creativity And Charisma Among Female Leaders: The Role Of Resources And Work Engagement. The International Journal of Human Resource Management, 24(14), 2760-2779. doi:10.1080/09585192.2012.751438

Bakker, A. B., Hakanen, J. J., Demerouti, E., \& Xanthopoulou, D. (2007). Job Resources Boost Work Engagement Particularly When Job Demands Are High. Journal of Educational Psychology, 99, 274-284.

Balnaves, M., \& Caputi, P. (2001). Introduction To Quantitative Research Methods. London: SAGE Publications, Ltd doi: 10.4135/9781849209380.

Bartlett, K. R. (2001). The Relationship Between Training And Organisational Commitment: A Study In The Health Care Field. Human Resource Development Quarterly, 12(4), 335. doi:10.1002/hrdq.1001

Beck, R., and Harter, J. (2018). "Why great managers are so rare", available at: www.gallup.com/ workplace/231593/why-great-managers-rare.aspx

Becker, G. S. (1962). Investment In Human Capital: A Theoretical Analysis. The Journal of Political Economy, 70, 9-49. 
Becker, G. S. (1992). The Division of Labor, Coordination Costs, and Knowledge. The Quarterly Journal of Economics, 107(4). 1137-1160.

Blazej, M. (2018). Employee Engagement And Performance: A Systematic Literature Review. International Journal of Management and Economics, 54(3), 227-244. https://doi.org/10.2478/ijme-2018-0018

Boudreau, J. W., Ramstad, P. M., \& Dowling, P. J. (2015). Global Talenship: Toward a Decision Science Connecting Talent to Global Strategic Success. Advances in Global Leadership, 3,63-99.

Burgard, C., \& Görlitz, K. (2014). Continuous Training, Job Satisfaction And Gender: An Empirical Analysis Using German Panel Data. Evidence-Based HRM: A Global Forum for Empirical Scholarship, 2(2), 126-144. doi.org/10.1108/EBHRM-11-2012-0016

Cammann, C., Fichman, M., Jenkins, D., \& Klesh, J. (1979). The Michigan Organisational Assessment Questionnaire. Unpublished Manuscript, University of Michigan, Ann Arbor, MI.

Cascio, W. F., \& Boudreau, J. W. (2016). The Search For Global Competence: From International HR To Talent Management. Journal of World Business, 51(1), 103-114. doi:10.1016/j.jwb.2015.10.002

Cheng, Y., \& Waldenberger, F. (2013). Does Training Affect Individuals Turnover Intention? Evidence From China. Journal of Chinese Human Resources Management, 4(1), 16-38. doi:10.1108/jchrm-10-2012-0024

Chew, J., \& Chan, C. C. (2008). Human Resource Practices, Organisational Commitment And Intention To Stay. International Journal of Manpower, 29(6), 503-522. doi:10.1108/01437720810904194

Chhabra, N. L., \& Mishra, A. (2008). Talent Management And Employer Branding: Retention Battle Strategies. Journal of Management Research, 7(11), 50-61

Christensen, R. (2005). Roadmap to Strategic HR: Turning a Great Idea into a Business Reality. Saranac Lake, NY: AMACOM Books

Clifford, J., \& Thorpe, S. (2007) More Ways Than One . . Exploring The Use Of Different Learning Methods In Organisations. Industrial and Commercial Training, 39(5), 267-271

Cooper, D. \& Schindler, P. (2011). Business Research Methods. 11th Edition, McGraw Hill, Boston

Dai, Y., Zhuang, W., \& Huan, T. (2019). Engage or Quit? The Moderating Role Of Abusive Supervision Between Resilience, Intention To Leave And Work Engagement. Tourism Management, 70, 69-77. doi.org/10.1016/j.tourman.2018.07.014

Deckop, J. R., Konrad, A. M., Perlmutter, F. D., \& Freely, J. L. (2006). The Effect Of Human Resource Management Practices On The Job Retention Of Former Welfare Clients. Human Resource Management, 45(4), 539-559. doi:10.1002/hrm.20131,

Demerouti, E., \& Bakker, A.B. (2011). The Job Demands- Resources Model: Challenges for Future Research. SA Journal of Industrial Psychology, 37(2), 9 pages. doi:10.4102/ sajip. v37i2.974

Di lorio, C. K. (2005). Measurement in Health Behaviour: Methods For Research Evaluation. Chapter 10. JosseyBass, San Francisco, USA, pp. 176-210.

Dubey, R., \& Gunasekaran, A. (2015). Shortage Of Sustainable Supply Chain Talent: An Industrial Training Framework. Industrial and Commercial Training, 47, 86-94. doi.org/10.1108/ICT-08-2014-0052

Festing, M., \& Schäfer, L. (2014). Generational Challenges to Talent Management: A Framework For Talent Retention Based On The Psychological-Contract Perspective. 
Journal of World Business, 49(2), 262-271.

Fletcher, L., Alfes, K., \& Robinson, D. (2018). The Relationship Between Perceived Training and Development and Employee Retention: The Mediating Role Of Work Attitudes. International Journal of Human Resource Management, 29(18).

Gallardo-Gallardo, E., Thunnissen, M., \& Scullion, H. (2017). Special issue of International Journal of HR. A contextualized approach to Talent Management: Advancing the field, The International Journal of HR, DOI: 10.1080/09585192.2016.1275292

Garavan, T. N., Carbery, R., \& Rock, A. (2012). Mapping Talent Development: Definition, Scope And Architecture. European Journal of Training and Development, 36(1), 5-24. doi.org/10.1108/03090591211192601

Ghazali, H., Mohamad-Nashuki, N., \& Othman, M. (2014). The Relationship Between Perceived Organisational Supports (POS) And Intention To Leave A Job Among Employees Of Casual Dining Restaurants In Klang Valley Area. Theory and Practice in Hospitality and Tourism Research, 425-429. doi:10.1201/b17390-85

Ghosh, P., Satyawadi, R., Joshi, J. P., \& Shadman, M. (2013). Who Stays With You? Factors Predicting Employees Intention To Stay. International Journal of Organisational Analysis, 21(3), 288-312. doi:10.1108/ijoa-sep-2011-0511

Gupta, M., \& Shaheen, M. (2017). Impact Of Work Engagement On Turnover Intention: Moderation By Psychological Capital In India. Business: Theory and Practice, 18(1), 136 143. doi:10.3846/btp.2017.014

Harter, J. K., Schmidt, F. L., \& Hayes, T. L. (2002). Business-Unit-Level Relationship Between Employee Satisfaction, Employee Engagement, And Business Outcomes: A MetaAnalysis. Journal of Applied Psychology, 87, 2, 268-279

Huang, W., \& Su, C. (2016). The Mediating Role Of Job Satisfaction In The Relationship Between Job Training Satisfaction And Turnover Intentions. Industrial and Commercial Training, 48(1), 42-52. doi:10.1108/ict-04-2015-0029

Huang, Y., Strawderman, L., Babski-Reeves, K., Ahmed, S., \& Salehi, A. (2013). Training Effectiveness and Trainee Performance in a Voluntary Training Program. Nonprofit and Voluntary Sector Quarterly, 43(6), 1095-1110. doi:10.1177/0899764013506787

Huertas-Valdivia, I., Llorens-Montes, F. J., \& Ruiz-Moreno, A. (2018). Achieving Engagement Among Hospitality Employees: A Serial Mediation Model. International Journal of Contemporary Hospitality Management, 30(1), 217-241. doi:10.1108/ijchm-09-20160538

Ikuomola, O. A. (2015). Learning and Talent Development: A Review. International Journal Of Advanced Research in Engineering \& Management, 01(02), 98-111.

Isa, A., Ibrahim, H. I., Jaaffar, A. H., \& Baharin, N. L. L. (2018). Talent Management Practices, Perceived Organisational Support and Employee Retention : Evidence From Malaysian Government-Linked Companies. Global Business and Management Research: An International Journal, 10(3), 688-697.

Joo, B., \& Lee, I. (2017). Workplace Happiness: Work Engagement, Career Satisfaction, And Subjective Well-Being. Evidence-based HRM: A Global Forum for Empirical Scholarship, 5(2), 206-221. doi:10.1108/ebhrm-04-2015-0011

Kahn, W. A. (1990). Psychological Conditions Of Personal Engagement And Disengagement At Work. Academy of Management Journal, 33(4), 692-724.

Karatepe, O. M., \& Olugbade, O. A. (2016). The Mediating Role Of Work Engagement In The Relationship Between High-Performance Work Practices And Job Outcomes Of Employees In Nigeria. International Journal of Contemporary Hospitality Management, 
28(10), 2350-2371. doi:10.1108/ijchm-03-2015-0145

Karatepe, O. M. (2013). Perceptions Of Organisational Politics And Hotel Employee Outcomes: The Mediating Role Of Work Engagement. International Journal of Contemporary Hospitality Management, 25(1), 82-104.

Karavardar, G. (2014). Organisational Career Growth and Turnover Intention: An Application in Audit Firms in Turkey. International Business Research, 7(9), 67.

Khawaja \& Nadeem. (2013). Training and Development Program and its Benefits to Employee and Organisation: A Conceptual Study. European Journal of Business and Management. 5(2), 2013.

Kim, H., Kang, D., Lee, S., \& Mclean, G. (2015). Career Commitment as a Mediator between Organisation-Related Variables and Motivation for Training and Turnover Intentions. Journal of Career Development, 43(2), 130-144. doi:10.1177/0894845315584160

Knassmuller, M., \& Veit, S. (2016). Culture Matters - The Training Of Senior Civil Servants In Austria, Germany, The Netherlands And Switzerland. Teaching Public Administration, 34(2), 120-149. doi.org/10.1177/0144739415620949

Lee, T. W., Hom, P., Eberly, M., \& Li, J. (2018). Managing Employee Retention And Turnover With 21st Century Ideas. Organizational Dynamics, 47(2), 88-98. doi: 10.1016/j.orgdyn.2017.08.004

Llorens, S., Bakker, A. B., Schaufeli, W., \& Salanova, M. (2006). Testing The Robustness Of The Job Demands-Resources Model. International Journal of Stress Management, 13(3), 378391. doi.org/10.1037/1072-5245.13.3.378

Lu, L., Lu, A.C.C., Gursoy, D. \& Neale, N.R. (2016). Work Engagement, Job Satisfaction, And Turnover Intentions: A Comparison Between Supervisors And Line-Level Employees. International Journal of Contemporary Hospitality Management, 28(4), 737-761.

Malhotra, N.K. (2004). Marketing Research. Prentice Hall, New Jersey.

McElroy, J. C., \& Weng, Q. (2016). The Connections Between Careers and Organisations in the New Career Era: Questions Answered, Questions Raised. Journal of Career Development, 43(1), 3-10. doi.org/10.1177/0894845315604738

Mehdiabadi, A. H., \& Li, J. (2016). Understanding Talent Development and Implications for Human Resource Development. Human Resource Development Review, 15(3), 263-294. doi:10.1177/1534484316655667

Mehrez, A., \& Bakri, A. (2019). The Impact Of Human Resource Practices On Job Satisfaction And Intention To Stay In Emerging Economies: Model Development And Empirical Investigation Among High Caliber Governmental Employees In Qatar. Management Science Letters, 425-442. doi:10.5267/j.msl.2018.12.007

Memon, M. A., Rohani Salleh, \& Baharom, M. N. R. (2016). The Link Between Training Satisfaction, Work Engagement And Turnover Intention. European Journal of Training and Development, 40(6), 407-429. doi.org/10.1108/02656710210415703

Memon, M. A., Salleh, R., Nordin, S. M., Cheah, J.-H., Hiram Ting, \& Chuah, F. (2018). PersonOrganisation Fit And Turnover Intention: The Mediating Role Of Work Engagement. Journal of Management Development, 37(3), 285-298.

Milliman, J., Gatling, A., \& Kim, J. (2018). The Effect Of Workplace Spirituality On Hospitality Employee Engagement, Intention To Stay, And Service Delivery. Journal of Hospitality and Tourism Management, 35, 56-65. doi:10.1016/j.jhtm.2018.03.002

Nawaz, M. S., Pangil, F., \& Bhatti, M. A. (2015). The Relationship between Human Resource Development Factors and Turnover Intention : A Conceptual Framework. International Journal of Academic Research in Business and Social Sciences, 5(12), 297-310. 
doi.org/10.6007/IJARBSS/v5-i12/1959

Neuman, W. L. (2011). Social Research Methods: Qualitative and Quantitative Approaches. 7th Edition, Pearson, Boston.

Nguyen, L. T. \& Shao, Y. (2019). The Impact of Training on Turnover Intention: The Role of Growth Need Strength among Vietnamese Female Employees', The South East Asian Journal of Management, 13(1), 1-17.

Nkechi, P. A., \& Dialoke, I. (2017). Effects of Career Growth on Employees Performance : A Study of Non-Academic Staff of Michael Okpara University of Agriculture Umudike Abia State, Nigeria. Singaporean Journal of Business Economics and Management Studies, 5(7), 8-18. doi:10.12816/0037246

Pandita, D., \& Ray, S. (2018). Talent Management And Employee Engagement - A MetaAnalysis Of Their Impact On Talent Retention. Industrial and Commercial Training, 50(4), 185-199. doi.org/10.1108/ICT-09-2017-0073

Patrick, J. (2000). (Ed.), Training. Introduction To Work And Organisational Psychology, 100125. Oxford, UK: Blackwell.

Rothmann, S., \& Joubert, S. R. (2010). Factors Associated With Employee Engagement In South Africa. SA Journal of Industrial Psychology, 36(2). doi:10.4102/sajip.v36i2.925

Schaufeli, W. B., \& Bakker, A. B. (2004). Job Demands, Job Resources And Their Relationship With Burnout And Engagement: A Multi Sample Study. Journal of Organisational Behavior, 25, 293-315. doi.org/10.1002/job.248

Schaufeli, W. B., Bakker, A. B., \& Salanova, M. (2006). The Measurement Of Work Engagement With A Short Questionnaire: A Cross-National Study. Educational and Psychological Measurement, 66, 701-716. doi:10.1177/0013164405282471

Schein, E. H., \& Van Maanen, J. (2016). Career Anchors And Job/Role Planning: Tools For Career And Talent Management. Organisational Dynamics, 45(3), 165-173. doi.org/10.1016/j.orgdyn.2016.07.002

Schmidt, S. W. (2007). The Relationship Between Satisfaction With Workplace Training And Overall Job Satisfaction. Human Resource Development Quarterly, 18(4), 481-498. doi:10.1002/hrdq.1216

Scullion, H., \& Collings, D.G. (2011). Global Talent Management. London: Routledge.

Sekaran, U., \& Bougie, R. (2010). Research Methods for Business (5th edition). Chichester, West Sussex, United Kingdom: John Wiley.

Semwal, M., \& Dhyani, A. (2017). Impact Of Employees Training And Career Development On Their Engagement - A Study Using OCM And UWES Measurement Scales. Journal of Business, 12(1), 85-101.

Sheehan, C., Tham, T. L., Holland, P., \& Cooper, B. (2019). Psychological Contract Fulfilment, Engagement And Nurse Professional Turnover Intention. International Journal of Manpower, 40(1), 2-16. doi:10.1108/ijm-08-2017-0211

Sheehan, M. (2012). Developing Managerial Talent: Exploring The Link Between Management Talent And Perceived Performance In Multinational Corporations (MNCs). European Journal of Training and Development, 36(1), 66-85. doi.org/http://dx.doi.org/10.1108/03090591211192638

Tlaiss, H. A., Martin, P., \& Hofaidhllaoui, M. (2017). Talent Retention: Evidence From A Multinational Firm In France. Employee Relations, 39(4), 426-445. doi.org/10.1108/ER07-2016-0130

Weng, Q., \& McElroy, J. C. (2012). Organisational Career Growth, Affective Occupational Commitment And Turnover Intentions. Journal of Vocational Behavior, 80(2), 256-265. 
doi.org/10.1016/j.jvb.2012.01.014

Weng, Q., McElroy, J. C., Morrow, P. C., \& Liu, R. (2010). The Relationship Between Career Growth And Organisational Commitment. Journal of Vocational Behavior, 77(3), 391400. doi.org/10.1016/j.jvb.2010.05.003

World Health Report.

(2016).

Retrived

from

https://www.who.int/gho/publications/world_health_statistics/2016

Yang, Y., Liu, Y., Liu, J., \& Zhang, H. (2015). The Impact Of Work Support And Organisational Career Growth On Nurse Turnover Intention In China. International Journal of Nursing Sciences, 2(2), 134-139. doi:10.1016/j.ijnss.2015.04.006

Zheng, Y., and Kleiner, B. H. (2001). Developments Concerning Career Development and Transition. Management Research News, 24(3/4), 33-44. 